University of Nebraska - Lincoln

DigitalCommons@University of Nebraska - Lincoln

Coevolution and Biogeography Among Nematodirinae (Nematoda: Trichostrongylina) Lagomorpha and Artiodactyla (Mammalia): Exploring Determinants of History and Structure for the Northern Fauna Across the Holarctic

Eric P. Hoberg

USDA-ARS, eric.hoberg@ars.usda.gov

Follow this and additional works at: https://digitalcommons.unl.edu/parasitologyfacpubs

Part of the Parasitology Commons

Hoberg, Eric P., "Coevolution and Biogeography Among Nematodirinae (Nematoda: Trichostrongylina) Lagomorpha and Artiodactyla (Mammalia): Exploring Determinants of History and Structure for the Northern Fauna Across the Holarctic" (2005). Faculty Publications from the Harold W. Manter Laboratory of Parasitology. 734.

https://digitalcommons.unl.edu/parasitologyfacpubs/734

This Article is brought to you for free and open access by the Parasitology, Harold W. Manter Laboratory of at DigitalCommons@University of Nebraska - Lincoln. It has been accepted for inclusion in Faculty Publications from the Harold W. Manter Laboratory of Parasitology by an authorized administrator of DigitalCommons@University of Nebraska - Lincoln. 


\title{
COEVOLUTION AND BIOGEOGRAPHY AMONG NEMATODIRINAE (NEMATODA: TRICHOSTRONGYLINA) LAGOMORPHA AND ARTIODACTYLA (MAMMALIA): EXPLORING DETERMINANTS OF HISTORY AND STRUCTURE FOR THE NORTHERN FAUNA ACROSS THE HOLARCTIC
}

\author{
Eric P. Hoberg \\ U.S. National Parasite Collection and the Animal Parasitic Diseases Laboratory, USDA, Agricultural Research Service, BARC East No. 1180 \\ 10300 Baltimore Avenue, Beltsville, Maryland 20705-2350. e-mail: ehoberg@anri.barc.usda.gov
}

\begin{abstract}
Nematodes of the subfamily Nematodirinae are characteristic components of a Holarctic fauna. The topology of a generic-level phylogenetic hypothesis, patterns of diversity, and geographic distributions for respective nematode taxa in conjunction with data for host occurrence are consistent with primary distributions determined across Beringia for species of Murielus, Rauschia, Nematodirus, and Nematodirella. Ancestral hosts are represented by Lagomorpha, with evidence for a minimum of 1 host-switching-event and subsequent radiation in the Artiodactyla. Diversification may reflect vicariance of respective faunas along with episodic or cyclical range expansion and isolation across Beringia during the late Tertiary and Quaternary. Secondarily, species of Nematodirus attained a distribution in the Neotropical region with minimal diversification of an endemic fauna represented by Nematodirus molini among tayassuids, Nematodirus lamae among camelids and Nematodirus urichi in cervids during the Pleistocene. Nematodirines are a core component of an Arctic-Boreal fauna of zooparasitic nematodes (defined by latitude and altitude) adapted to transmission in extreme environments characterized by seasonally low temperatures and varying degrees of desiccation. The history and distribution of this fauna is examined in the context of biotic and abiotic determinants for geographic colonization and host switching with an exploration of predicted responses of complex host-parasite systems to ecological perturbation under a regime of global climate change.
\end{abstract}

Nematodirinae is a monophyletic group within the Trichostrongylina and Molineoidea represented by species among 5 genera distributed among mammalian hosts across the Holarctic (Durette-Desset, 1983; Hoberg et al., 2005). Species of nematodirines are characteristic parasites in Artiodactyla and Lagomorpha but seldom Rodentia, and usually generic taxa are of low diversity, either being monotypic or with $\leq 6$ species, except for the speciose Nematodirus. Among lagomorphs, there are 3 species of Murielus Dikmans, 1939, that are characteristic parasites in pikas (Ochotonidae: Ochotona spp.) from the $\mathrm{Pa}$ learctic and Nearctic, respectively (Dikmans, 1939; DuretteDesset, 1974). Rauschia Durette-Desset, 1979, was established for 5 species (formerly Nematodirus) in Leporidae from the Nearctic and Palearctic (Dikmans, 1937; Durette-Desset, 1979). Nematodiroides Bernard, 1967, is monotypic, with Nematodiroides zembrae (Bernard, 1965) occurring in leporids, from the western Palearctic (Bernard, 1967; Durette-Desset, 1979). In contrast, there are 2 genera in artiodactyls, including 6 species of Nematodirella Yorke and Maplestone, 1926, distributed among Camelidae, Cervidae, Antilocapridae, Bovinae, Antilopinae, and Caprinae across the Holarctic (Lichtenfels and Pilitt, 1983b), and approximately 40-50 species of Nematodirus Ransom, 1907, primarily among pecoran ruminants, but rarely among Camelidae and Tayassuidae, of the Holarctic and Neotropical regions (Kulmamatov, 1974; Rossi, 1983); 2 species occur in rodents. Nematodirines are essentially a group associated with the boreal to high latitudes of the Holarctic and are absent from Africa and southern Asia, although some species of Nematodrius are now cosmopolitan in their distributions and have been introduced globally, including Australia and New Zealand (e.g., Andrews, 1973; Beveridge and Ford, 1982), with translocation of domestic stock.

Although scenarios for some aspects of evolution, host relationships, and historical biogeography within the subfamily

Received 11 March 2004; revised 20 July 2004; accepted 20 July 2004. have been summarized, these concepts had not been developed in the context of robust phylogenetic hypotheses for the group (e.g., Durette-Desset, 1978, 1979, 1985; Rossi, 1983; DuretteDesset et al., 1994). Only the putative relationships among species of Nematodirus or Nematodirella have been explored based on application of phylogenetic methods (e.g., Lichtenfels and Pilitt, 1983a, 1983b; Hoberg, 1997; Audebert et al., 2000; Nadler et al., 2000). Hoberg et al. (2005) developed the first phylogenetic hypotheses for the nematodirines and demonstrated monophyly for the subfamily and its 5 inclusive genera.

In excluding Lamanema chavezi from the Nematodirinae, Hoberg et al. (2005) indicated the necessity for a complete revision of ideas about historical biogeography and coevolution among this group of nematodes and their hosts. In the current study, I articulate and explore new hypotheses for the history and host associations for nematodirine nematodes that are based on and constrained by the putative phylogenetic relationships of this monophyletic group.

An integrative process in historical reconstruction is linked to a strong phylogenetic foundation and relies on (1) an examination of comprehensive empirical data for host distribution and geographic range for nematodirines including both genera and species, (2) an exploration of abiotic determinants of distribution for complex host-parasite systems, and (3) development of explicit and testable hypotheses for coevolutionary history and biogeography for nematodirines and their mammalian hosts. In a comparative framework, generalities in the distributional history for a diverse assemblage of nematodes, including some Trichostrongylidae, Molineidae, and Protostrongylidae, and the structure of the Holarctic fauna during the Late Tertiary and Quaternary are further explored (e.g., Hoberg et al., 1995, 1999, 2003). Such historical studies provide an analogue for identifying and predicting patterns of response by complex parasite-hosts systems to ecological perturbation driven by global change (e.g., Hoberg, 1997; Hoberg et al., 2001; Kutz et al., 2004). Collectively, such studies emphasize the continuing need for comprehensive survey and inventory and a 


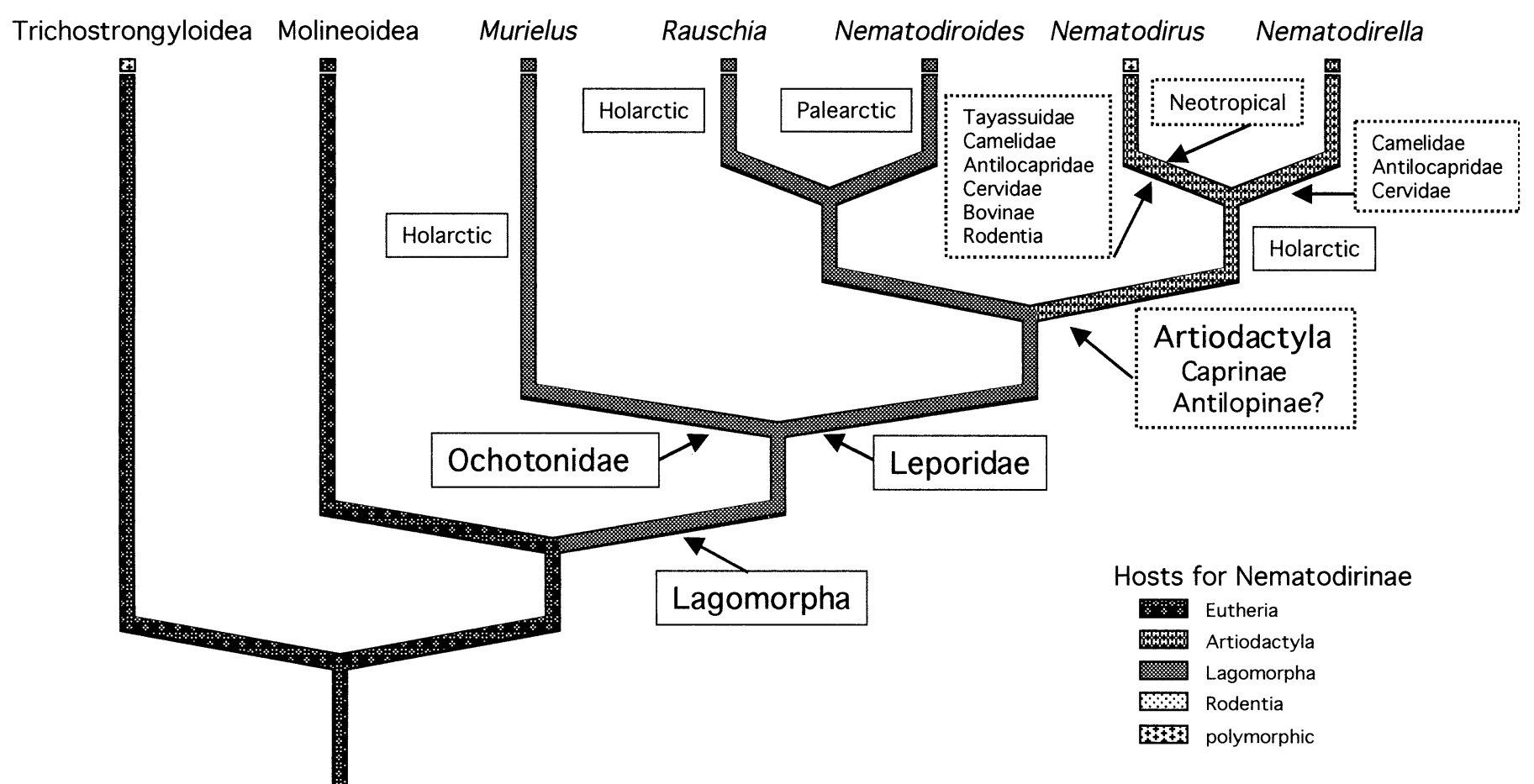

FIGURE 1. Host and biogeographic associations for genera of the Nematodirinae. Phylogenetic analysis shown in Hoberg et al. (2005) resulted in a single most parsimonious tree for relationships among genera of nematodirines. In the current study, host and geographic data have been mapped and optimized onto this fully resolved tree for the nematodirines using MacClade 4.0 (Maddison and Maddison, 2000). Murielus, Rauschia, and Nematodiroides are associated with lagomorph hosts, and initial diversification may coincide with the divergence of ochotonids and leporids. Association of nematodirines and artiodactyls is linked to a single colonization event from a leporid host. Radiation of Nematodirus initially involved Caprini and Rupicaprini in Eurasia, followed by a complex history of dispersal and colonization in the Nearctic and Neotropical regions; this is further corroborated by species-level analyses that examined relationships among a limited number of hosts and parasite species (Hoberg, 1997). Nematodirella is an Arctic-adapted group, with a history linked to high latitudes in caprines and possibly antelopes such as Gazella subguttorosa, with secondary colonization of Camelus, Antilocapra, and cervids. Consult text for details. Boxes circumscribed by dashed lines denote instances of putative colonization. Lamanema is pruned from the tree, as it has no bearing on understanding the history of inclusive genera and species of the nematodirines. Hosts for Trichostrongyloidea include Eutheria (rodents, lagomorphs, artiodactyls), whereas those for Molineoidea include Eutheria (Xenarthra, Pholidota, Tubulidentata, and archaic rodents), Amphibia, and reptiles (Durette-Desset, 1985; Hoberg and Lichtenfels, 1994).

phylogenetic context for hosts and parasites in defining historical associations across the Holarctic (Brooks and Hoberg, 2000; Brooks and McLennan, 2002; Hoberg et al., 2003).

\section{MATERIALS AND METHODS}

\section{Parasite phylogeny}

Phylogenetic analysis among the Nematodirinae constitutes the foundation for comparative studies in biogeography and coevolution for hosts and parasites. The robust hypothesis for relationships among the genera, Murielus, Rauschia, Nematodiroides, Nematodrius, and Nematodirella, represents the primary comparative basis for the current study (Hoberg et al., 2005).

\section{Hosts and biogeography}

Empirical data for host evolution, historical biogeography, and geological history, along with ecological data for host associations and geographic distributions of this diverse assemblage of parasites, are first concisely summarized and then examined within an integrative framework linked to the nematodirine phylogeny. Data for host association and geographic distribution were derived from reviews and the primary literature (e.g., Travassos, 1937; Sarwar, 1956; Skrjabin et al., 1954; Boev et al., 1963; Durette-Desset, 1979; Lichtenfels and Pilitt, 1983a, 1983b; Sutton and Durette-Desset, 1985; Hoberg et al., 2001). Data specifying host and geographic distributions were mapped onto the phylogeny for the Nematodirinae to develop and examine hypotheses for historical relationships using MacClade 4.0 (see Maddison and Maddison, 2000).

Concepts for mammalian taxonomy are consistent with Wilson and Reeder (1993) and Shackleton and Lovari (1997); taxonomy for Ochotonidae (Lagomorpha) is based on Smith et al. (1992). Timeframes for the history of this assemblage are designated as mybp (million years before present) or kybp (thousand years before present). Historical data for hosts, including origins, first occurrences, and patterns of range expansion were derived from the primary literature and detailed reviews (e.g., Kurtén and Anderson, 1980).

\section{RESULTS}

\section{Hosts and biogeography}

Host and geographic associations were mapped directly onto the parasite phylogeny to examine hypotheses for historical relationships; Lamanema was been pruned from this tree as a relationship to Molineinae, or the Trichostrongyloidea remains equivocal (Fig. 1) (Hoberg et al., 2005). Species diversity for respective genera was reviewed to establish a comprehensive and more refined understanding of geographic and host distributions for smaller taxa and for Nematodirus. Host and geographic records for all species of nematodirines are summarized from reviews and original taxonomic works (e.g., Skrjabin et al., 1954; Durette-Desset, 1979; Lichtenfels and Pilitt, 1983b; 
Govorka et al., 1988; Hoberg et al., 2001). These empirical data are first summarized and then evaluated in the context of the generic-level phylogeny and monophyly for respective genera of the nematodirines.

Basal nematodirines represented by Murielus, and later Rauschia + Nematodiroides diversified among lagomorph hosts, and there was a single colonization event to the artiodactyls resulting in host associations for Nematodirus + Nematodirella. This is compatible with ancestral hosts for the nematodirines being represented by Lagomorpha, with a history of secondary diversification of a nematodirine fauna among families and subfamilies of Artiodactyla following colonization (Fig. 1).

Ancestral hosts for Murielus and Rauschia + Nematodiroides are represented by lagomorphs, with initial diversification linked to divergence of Ochotonidae and Leporidae in Eurasia (Fig. 1). Murielus is represented by 3 species: (1) Murielus harpespiculus Dikmans, 1939, in Ochotona princeps (Richardson) from the Nearctic and $O$. hyperborea (Pallas) from the Palearctic; (2) Murielus tjanschaniensis Gvozdev, 1962, in $O$. alpina (Pallas) and O. roylei (Ogilby) from Kirgizstan and Khazakhstan; and (3) Murielus abei Durette-Desset, 1974, in $O$. roylei from Nepal in the eastern Palearctic. A Holarctic distribution for Murielus is compatible with origins in the Palearctic associated with Ochotona, range expansion across Beringia into the Nearctic, and subsequent isolation with populations of pikas in Eurasia and North America.

In contrast, species of Rauschia and Nematodiroides zembrae are specific to Leporidae. Nematodiroides is restricted to the western Palearctic and North Africa in Oryctolagus cuniculus (Linnaeus) and Lepus capensis Linnaeus. Rauschia contains 2 species from the Palearctic, including $R$. aspinosus (Shul'ts, 1931 ) in L. timidus Linnaeus and $R$. petrovi (Ivashkin, 1954) in L. tolai Pallas; and 2 species from the Nearctic, namely $R$. triangularis (Boughton, 1932) in L. americanus Erxleben and L. alleni Mearns, and R. neomexicanus (Dikmans, 1937) in $L$. californicus Gray and Sylvilagus nuttalli (Bachman). Rauschia leporis (Chandler, 1924), a species described in O. cuniculus (domestic rabbit) from Texas, has an ambiguous distributional history.

Species of Nematodirus and Nematodirella collectively have Holarctic distributions and are specific primarily among pecoran ruminants, with minimal diversity represented among the Tayassuidae and Camelidae. Species in the diverse genus Nematodirus are generally restricted to either the Palearctic or $\mathrm{Ne}$ arctic, whereas relatively few species among wild ruminants have widespread ranges across the Holarctic; 3 species, $N$. molini (Railliet, 1898) in Tayassu pecari (Link) (reported as $T$. albirostris) and Pecari tajacu (Linnaeus) from Brazil; N. lamae Becklund, 1963, in Lama pacos (Linnaeus), L. glama (Linnaeus), and Vicugna vicugna (Molina) from Peru; and N. urichi Cameron, 1936, in Mazama americanus (Erxleben) from Trinidad, are endemic to the Neotropical region. The extensive cosmopolitan ranges for those species in domestic Caprinae (e.g., N. spathiger (Raillet and Henry, 1896), N. filicollis (Rudolphi, 1802), N. abnormalis May, 1920, and N. battus) and some Bovinae ( $N$. helvetianus May, 1920) are in part compatible with recent historical or contemporary translocation with infected hosts. Additionally, Nematodirus wienbergi Railliet and Henry, 1909, in Pan troglodytes (Gmelin) from Africa represents a species inquirenda due to an ambiguous and incomplete de- scription and consequently the record has no historical or biogeographic significance.

Although ruminants are the core host group for Nematodirus, 2 species are known in rodents. Nematodirus mugosaricus Shul'ts, 1926, is a parasite in Spermophilus pygmaeus (Pallas) from Russia and $N$. neotoma Hall, 1916 (synonomy $=N$. tortuosus Tucker, 1942), occurs in Neotoma cinerea (Ord), N. floridana (Ord), N. fuscipes (Baird), $N$. lepida Thomas, and $N$. mexicana Baird, from the western Nearctic. Geographically discrete ranges and occurrence in phylogenetically disparate Sciuridae and Cricetidae is compatible with a history of independent colonization.

Nematodirella represents an assemblage of 6 species occurring in Camelidae, Cervidae, Caprinae, and Antilopinae at temperate/boreal to high latitudes of the Holarctic. Broad ranges encompassing the Holarctic are documented for $N$. alcidis (Dikmans, 1935) in Alces alces (Linnaeus), Capreolus capreolus (Linnaeus), Cervus elaphus Linnaeus, and Ovibos moschatus (Zimmermann); N. longissimespiculata (Romanovich, 1915) in A. alces, C. capreolus, Rangifer tarandus (Linnaeus) (reindeer and caribou), and $O$. moschatus, and $N$. gazelli (Sokolova, 1948) in Saiga tatarica (Linnaeus), Gazella subgutturosa (Guldenstaedt), O. moschatus, and A. alces. In Eurasia, 2 species are characteristic in Camelidae: $N$. cameli (Rajewskaya and Badanin, 1933) in Camelus bactrianus Linnaeus (rare records in cervids and bovids) and $N$. dromedarii (May, 1920) in $C$. dromedarius Linnaeus and $G$. subgutturosa from India and Iran. In the northwestern Nearctic, N. antilocaprae (Price, 1927) is a dominant parasite in Antilocapra americana (Ord), with sporadic records in Odocoileus hemionus (Rafinesque), C. elaphus, Ovis canadensis Shaw, and Oreamnos americanus (Blainville); distributions in Cervidae and Caprinae are likely to represent contemporary host switching from pronghorn in zones of contact or in sympatry.

Additional diversity may exist within Nematodirella. In Eurasia, N. mauritanicus Maupas and Seurat, 1912, was described based on specimens in Camelus dromedarius and C. bactrianus, and this species is also reported in C. capreolus and A. alces; with transfer of this species to Nematodirella, there would be no species of Nematodirus in Eurasian camelids. In the Arctic, $N$. tarandi Hadwin, 1922, was described from reindeer introduced to Alaska and subsequently was reported in $O$. moschatus. Specimens of both species have characters considered typical of Nematodirella, including spicules of great length, but their placement has not been unequivocally resolved.

The structure of the phylogeny for nematodirines, patterns of diversity, and geographic distributions for respective taxa (Fig. 1) in conjunction with more refined data for the occurrence of species within inclusive genera are consistent with primary distributions determined across Beringia for Murielus, Rauschia, Nematodirus, and Nematodirella. Diversification may reflect vicariance of respective faunas along with episodic or cyclical range expansion and isolation across Beringia during the late Tertiary and Quaternary. Ancestral hosts are represented by Lagomorpha, with evidence for a minimum of 1 host-switchingevent and subsequent radiation in the Artiodactyla (Fig. 1). Secondarily, Nematodirus attained a distribution in the Neotropical region with minimal diversification of an endemic fauna represented by $N$. molini among tayassuids, $N$. lamae among ca- 
melids, and $N$. urichi in cervids (Odocoileinae, Odocoileini) during the Pleistocene.

\section{DISCUSSION}

\section{Basic historical context}

Durette-Desset (1978) and Sutton and Durette-Desset (1985) concluded that Lamanema represented a transitional form between the Molineinae and Nematodirinae. This contention of a relationship for Lamanema and basal nematodrines was refuted in phylogenetic analyses that established monophyly for the subfamily and concurrently excluded this monotypic genus based on assessment of characters from comparative morphology (Hoberg et al., 2005). Consequently, the historical relationships for the nematodirines require further examination as the putative ancestral position for Lamanema figured prominently in hypotheses about evolution of these nematodes. These interpretations were central to assumptions about a putative ancestral association for nematodirines and camelids and a relictual status for N. lamae in the Neotropical region (e.g., Rossi, 1983; Durette-Desset, 1985; Durette-Desset et al., 1994).

\section{Host associations and historical biogeography}

Exclusion of Lamanema from the subfamily effectively refutes the concept of origin for the Nematodirinae, Nematodirus or Nematodirella, among camelids from the Nearctic or Neotropics (i.e., Durette-Desset and Chabaud, 1977, 1981; Lichtenfels and Pilitt, 1983b; Rossi, 1983; Durette-Desset, 1985; Durette-Desset et al., 1994). Nematodrines of ochotonids, Murielus spp., are basal and those in leporids, Rauschia + Nematodiroides, are the sister for Nematodirus + Nematodirella in artiodactyls. Thus, the nematodirines of Caprinae and secondarily those among other pecoran ruminants, camelids, and tayassuids have been derived via a single event of colonization from an ancestral fauna in lagomorphs (Fig. 1). Further, these data refute the hypothesis for derivation of a nematodirine fauna in lagomorphs by colonization from either caprines and cervids (Rossi, 1983) or as a consequence of a basal split, divergence, and radiation of discrete lineages of nematodes in lagomorphs or camelids and pecoran ruminants near the termination of the Oligocene (Durette-Desset and Chabaud, 1977, 1981; Rossi, 1983; Durette-Desset, 1985; Durette-Desset et al., 1994).

\section{Nematodirinae and Lagomorpha}

Limited diversity in Murielus and Rauschia essentially allows a more detailed discussion and development of hypotheses for historical biogeography in the Holarctic region and particularly across the Beringian nexus (Rausch, 1994; Hoberg et al., 2003). Ancestral hosts for the basal Murielus and for Rauschia + Nematodiroides are represented by lagomorphs, and initial diversification appears linked to divergence of Ochotonidae and Leporidae in Eurasia during the Oligocene (Fig. 1) (Dawson, 1967). Under a weak null hypothesis for cospeciation, the association of nematodrines and lagomorphs could thus extend considerably deeper than 25 mybp and account for the distribution of Murielus in Ochotonidae and Rauschia and Nematodiroides in Leporidae. Empirical evidence is not sufficient, however, to corroborate this hypothesis nor to choose among competing explanations for these distributions of an otherwise depauperate host-specific fauna. Our knowledge may be influenced by insufficient sampling, differential extinction, or patterns of late colonization. The limited diversity of these respective clades of host-specific parasites, however, suggests that contemporary distributions may represent relictual associations among Ochotonidae and Leporidae established early in the radiation of the lagomorphs.

Distributions among species of Ochtotona are restricted to the Holarctic, where respective species occur at northern temperate/boreal to arctic latitudes and often are associated with high-elevation habitats. Pikas are first known from Eurasia in the late Miocene and appear in the Nearctic during the late Pliocene (Yu et al., 2000); there are approximately 18-26 Recent species (Smith et al., 1992; Wilson and Reeder, 1993). Ochotona princeps in western North America occurs in insular and discontinuous alpine habitats and is considered to represent a single dispersal event across Beringia from Eurasia during the late Pliocene (Kurtén and Anderson, 1980; Hafner and Sullivan, 1995; Yu et al., 2000). In contrast, O. collaris (Nelson) is restricted to central Alaska and adjacent areas of the Yukon and northern British Columbia and may represent a peripheral isolate of an ancestral population close to $O$. princeps that was restricted to eastern Beringia by Cordilleran and continental glaciation in the late Pleistocene (Kurtén and Anderson, 1980; Rausch, 1994). Alternatively it may represent an independent range expansion from Chukhotka into eastern Beringia for Ochotona.

Species of Murielus are only known based on sporadic records from the northern and mountain pikas, which constitute putative sister groups that diverged 2.4 mybp; basal diversification in the northern group leading to the ancestor of $O$. princeps $+O$. collaris (?) is estimated at 2.1 mybp (Yu et al., 2000). In the northern group, $O$. princeps (and $O$. collaris) is the putative sister of $O$. pallasi Gray and $O$. alpina $+O$. hyperborea. Murielus is represented across the Holarctic by $M$. harpespiculus in $O$. princeps from western North America and apparently $O$. hyperborea (reported as O. alpina) from the Taimir Peninsula, Russia (Gvozdev et al., 1970; Seesee, 1973), in the eastern Palearctic by M. tjanschaniensis Gvozdev, 1962, in $O$. alpina and $O$. roylei from Kirgizstan and Khazakhstan and by M. abei Durette-Desset, 1974, in O. roylei from Nepal. Notably, Gvozdev et al. (1970) redetermined specimens of $M$. tjanschaniensis and reported the Altai pika (O. alpina) from the Taimir as the sole Palearctic record of $M$. harpespiculus. The host record must also be clarified, as only the northern or Siberian pika (O. hyperborea) occurs at this locality in north-central Siberia and current taxonomy recognizes $O$. hyperborea as distinct from O. alpina (Smith et al., 1992). Additionally, M. harpespiculus is unknown from relatively extensive collections of O. collaris in Alaska and the Yukon Territory (Hobbs, 1980), suggesting the possibility that the redetermination by Gvozdev et al. (1970) may be in error.

Apparently $M$. harpespiculus has not been reported in other members of the northern group, O. alpina, O. pallasi, or $O$. collaris, and with respect to the latter, may represent incomplete sampling in Alaska, an extinction event following isolation of an ancestral host population or evidence of the putative independence of $O$. collaris relative to $O$. princeps. Additionally, $O$. roylei is the only known host among 7 species of pikas within the mountain group, in which $M$. tjanschaniensis and $M$. 
abei may retain highly fragmented or allopatric distributions. Notably, there is an apparent absence of Murielus from any member of the shrub-steppe group of pikas that are restricted to Eurasia. We lack a phylogenetic hypothesis for the 3 species of Murielus and thus cannot postulate which may be basal, although, morphologically, M. harpespiculus and $M$. tjanschaniensis are similar and $M$. abei is divergent (Durette Desset, 1974). A Holarctic distribution for Murielus is generally compatible with origins in the Palearctic associated with Ochotona, range expansion across Beringia into the Nearctic, and subsequent isolation with populations of pikas in Eurasia and North America.

Providing a comparative context, species of Graphidiella Olsen, 1948, represent another host-specific assemblage of molineoids (Amphibiophilidae) in Ochotona (Durette-Desset and Tcheprakoff, 1983; Durette-Desset et al., 1994). Similar to $\mathrm{Mu}$ rielus, the host and geographic distributions among the 4 species, G. ochotonae Olsen, 1948, G. olsoni Gvozdev, 1966, G. szechuanensis $\mathrm{Wu}, 1977$, and G. nepalensis Durette-Desset and Tcheprakoff, 1983, are sporadic and fragmented with respective nematodes occurring primarily among northern and mountain groups of Ochotona. In the Nearctic, G. ochotonae occurs commonly in $O$. princeps but is unknown in O. collaris (Hobbs, 1980). Remaining species have distributions in the Palearctic, with $G$. olsoni occurring in $O$. alpina and $O$. daurica (the sole host species representing the shrub-steppe group) in eastern Siberia and the Altai, G. szechuanensis Wu, 1977, in Ochotona sp. from Sichuan Province, China, and G. nepalensis in O. roylei from Nepal. It remains to be determined if these distributions represent general biogeographic patterns for helminth parasites in pikas (e.g., Rausch and Ohbayashi, 1974; Rausch and Smirnova, 1984; Rausch, 1994).

Species of Rauschia and Nematodiroides zembrae are specific to Leporidae, and primarily, species of Lepus are recognized as hosts. Nematodiroides is restricted to the western Palearctic and North Africa in Oryctolagus cuniculus and Lepus capensis; its history is ambiguous but may represent isolation of a host-parasite assemblage in European leporids. As the sister group for Rauschia, this is compatible with a Palearctic distribution for these nematodirines in leporids (Fig. 1). Similar to species of Murielus, patchy or sporadic distributions for hostspecific nematodes are typical in the genus Rauschia; for example, 4 of 24-30 species of Lepus, 1 of 14 Sylvilagus, and the monotypic Oryctolagus are recognized as hosts. Rauschia leporis, a species described in $O$. cuniculus (domestic rabbit) from Texas, has an ambiguous distributional history in a secondarily cosmopolitan host that has been introduced globally. In the Palearctic, $R$. aspinosus occurs in L. timidus and $R$. petrovi in $L$. tolai (considered a synonym of $L$. capensis) from Mongolia; both host species have extensive geographic ranges, but it is not known to what degree parasite biogeography is congruent. Species of Rauschia are not known from Africa. In contrast, 2 species are unequivocally Nearctic in distribution, namely $R$. triangularis in $L$. americanus and $L$. alleni in a range from the Subarctic to southwestern United States, and $R$. neomexicanus in L. californicus and Sylvilagus nuttalli from Colorado and New Mexico. Rauschia neomexicanus has been considered a synonym of $R$. aspinosus, whereas $R$. arizonensis (Dikmans, 1937) was subsumed within $R$. triangularis by Tra- vassos (1937); the latter taxonomic decision is considered valid (Durette-Desset, 1979).

Interestingly, species of Rauschia are distributed in phylogenetically disparate subclades of leporids (Halanych et al., 1999). For example, $R$. aspinosus occurs in the Palearctic within the well-supported Arctic clade of Lepus but is unknown in either $L$. othus Merriam or $L$. arcticus Ross at high latitudes of Alaska or Canada and Greenland, respectively; such distributions could reflect environmental limitations on development and transmission. Alternatively, $R$. triangularis and $R$. neomexicanus occur in members of the Western American clade, including $L$. americanus and $L$. alleni, which have affinities with species of Lepus in the southwestern Nearctic (Halanych et al., 1999). Further, $R$. petrovi occurs in $L$. tolai which, with $L$. capensis, is the putative sister group for the Arctic + Western American clades. The occurrence of $R$. neomexicanus in $S$. nuttalli and absence of Rauschia among all other species of Sylvilagus is consistent with a secondary host switch from Lepus. These apparently divergent patterns suggest a complex history for Lepus and Rauschia, with the possibility of range expansion across Beringia from Eurasia for a discrete component of this broader host-parasite assemblage. Resolution of this history requires more detailed phylogenetic hypotheses for the leporids (Halanych et al., 1999) and analyses within Rauschia.

\section{Nematodirinae and Artiodactyla}

Nematodrines of leporids are the sister for those in artiodactyls, consistent with a host switch and radiation in Eurasia during the Early to Middle Miocene, 22-15 mybp. Mapping and optimization of host groups on the parasite phylogeny (Fig. 1) indicates an ancestral association for Nematodirus and Nematodirella among Caprinae and possibly Antilopinae in Eurasia, subsequent to range expansion, isolation, and radiation of the latter group in Africa after 16-14 mybp (see Vrba, 1985, 1995; Gatesy and Arctander, 2000; Vrba and Schaller, 2000; Hassanin and Douzery, 2003). Wild caprines do not have a continuous history in Africa and were extinct by the early Pleistocene (Vrba, 1985, 1995). These associations may explain the absence of endemic species of Nematodirus or Nematodirella in African camelids or pecoran ruminants. Diversification of Nematodirus and Nematodirella has been a consequence of colonization at varying temporal and geographic scales across the Holarctic.

The history for species of Nematodirus and Nematodirella was strongly associated with the Beringian region, the crossroads for the northern continents, linking the Palearctic and $\mathrm{Ne}$ arctic continually though much of the Tertiary and intermittently with episodic cycles of stadials and interstadials driving eustatic changes in sea level through the Pliocene and Quaternary (Hokpins, 1959, 1967; Kontrimavichus, 1976; Rausch, 1994; Sher, 1999; Hoberg et al., 2003). Distribution for these genera of nematodirines was further determined by a general trend for range expansion into the Nearctic by caprines (Caprini and Rupicaprini), antilopines (specifically Saiga tatarica), and cervids (Odocoileini and Rangiferini) during specific temporal windows extending from the Late Miocene, Pliocene, and Pleistocene (Kurtén and Anderson, 1980; Groves and Grubb, 1987; Webb, 2000). Dispersal events from the Nearctic to Palearctic during the late Pliocene and early Pleistocene involved few potential host groups other than the Camelidae (Webb, 1974; Kur- 
tén and Anderson, 1980), and none are now considered as significant determinants or drivers for diversification and distribution among either Nematodirus or Nematodirella. Hypotheses for an ancestral Nematodirus or nematodirines in Nearctic camelids and secondary range expansion to Palearctic with caprines and cervids following colonization of these ungulates in North America and the contemporary occurrence of a relictual fauna in Lamini of the Neotropical region is not supported (e.g., Rossi, 1983; Durette-Desset, 1985; Durette-Desset et al., 1994).

Nematodirus is the most speciose genus among nematodirines, occurs in the broadest spectrum of hosts, is geographically widespread, and includes endemic species in the Neotropics (3), Nearctic (6-7), northern Eurasia and the western Palearctic (approx. 26+), whereas another 7 species have Holarctic distributions either among wild caprines or global distributions via historical translocation and introduction with domestic stock. Maximum species diversity for Nematodirus coincides with that for caprine hosts in Eurasia (Shackleton and Lovari, 1997). Endemic species are not found in Africa or the tropical latitudes of Asia; species of Nematodirus are unknown in Eurasian $\mathrm{Ca}$ melus spp. if $N$. mauritanicus is referred to Nematodirella. (Lichtenfels and Pilitt, 1983b). Phylogenetic analysis among 11-15 of the approximately 40-50 species of Nematodirus revealed some insights into associations with ancestral hosts, putative coevolutionary relationships, and historical biogeography for species of this genus (Hoberg, 1997; Hoberg, unpubl. data).

Phylogenetic and historical analyses among species of $\mathrm{Nem}$ atodirus corroborate the putative basal association with Caprinae indicated through parsimony mapping in the current study (Fig. 1) (Hoberg, 1997). Among species of Nematodirus, the Caprinae (Caprini and Rupicaprini) and Cervidae (Odocoileinae) represent core host groups. Initial radiation of Nematodirus occurred in Eurasian caprines during the Middle to Late Miocene ( $\approx 15-10$ mybp), possibly following divergence from antelopes (see Vrba and Schaller, 2000; Hassanin and Douzery, 2003). Such would account for the high diversity for species of Nematodirus among caprines from Eurasia relative to the $\mathrm{Ne}$ arctic (Kulmamatov, 1974; Rossi, 1983; Hoberg et al., 2001).

A brief history for the Caprinae, Antilopinae, and related pecorans in the Holarctic is useful in understanding the biogeography of Nematodirus. Pecorans have origins in central Eurasia about 45 mybp; constituent families (e.g., Antilocapridae, Cervidae, and Bovidae) are recognized by the late Oligocene (29-24 mybp) and basal divergence and initial radiation among Bovinae, Antilopinae, and Caprinae occurred in the Early to Middle Miocene (22-15 mybp) (Hassanin and Douzery, 2003). Caprini and Rupicaprini are unknown in the Nearctic until Riss/ Illinoian time (600-300 kybp), when pachycerine sheep first entered and became established in eastern Beringia; with recession of continental glaciation during the Sangamon/RissWürm interstadial (300-200 kybp), sheep dispersed to the south and became widely distributed in western North America (Kurtén and Anderson, 1980). Subsequently, during the Wisconsin/ Würm stadial (200-10 kybp), pachycerine sheep were isolated in refugia south of the Cordilleran and Laurentide ice, leading to differentiation of Ovis canadensis (this is consistent with Korobitsnaya et al. (1974) and Geist (1985), who recognizes Ovis sp. in the Mojave Desert at 300 kybp). Populations of $O$. canadensis assumed their current ranges with northward expansion following deglaciation of the Rocky Mountains and reduc- tion of Cordilleran ice after 15 kybp (Geist, 1985). Concurrently, sequential isolation of Ovis populations in eastern and western Beringia by marine transgressions and expansion of the Bering Strait during the Sangamon and later in the Holocene, resulted in differentiation of $O$. nivicola Eschscholtz and $O$. dalli Nelson. Dall's sheep are recognized in eastern Beringia during the Wisconsin maximum (Kurtén and Anderson, 1980) and later became distributed in isolated populations in Alaska and adjacent regions of the Yukon, Northwest Territories, and northern British Columbia.

Mountain goats, Oreamnos americanus (Rupicaprini), appear to have a biogeographic history that parallels that of pachycerine sheep in North America, with discrete populations isolated in Beringia and south of the continental glaciers; contemporary ranges were determined in the Holocene by dispersal out of northern and southern refugia. In contrast, muskoxen are first known from central Europe and expanded into eastern Beringia during Kansan/Günz time (900-700 kybp), dispersed to the south during the Yarmouth interglacial, and occurred in periglacial habitats south of Laurentide ice during Riss/Illinoian time (600-300 kybp). Ovibos moschatus and Symbos cavifrons (Leidy) were sympatric for much of the late Pleistocene and occurred in both Beringia and south of the continental glaciers during the Wisconsin; O. moschatus remained extant following the Pleistocene at high latitudes of the Holarctic. Additionally, Antilopinae have been rarely represented in the Nearctic and Saiga tatarica is known following dispersal from Eurasia and Siberia during the middle Pleistocene and was extant in Beringia until the late Wisconsin (Kurtén and Anderson, 1980; Guthrie, 1982; Vereshchagin and Baryshnikov, 1982); other antelopes, including Gazella subguttorosa, are unknown in the Nearctic. Bison are the only Holarctic Bovinae to have survived the Pleistocene in North America, and Bison bison (Linnaeus) originated following immigration from Beringia during the Sangamon followed by vicariance and isolation of populations south of the continental glaciers during the Wisconsin (Kurtén and Anderson, 1980).

Similar to other pecorans, the origins and radiation of the Cervidae are linked to Eurasia during the Miocene, with the initial divergence of Cervinae (Cervini and Muntiacini) and Odocoileinae (Odocoileini and Rangiferini) (Groves and Grubb, 1987; Webb, 2000). Cervids were established in eastern Beringia by 3.0 mybp and species among 3 tribes, Odocoileini (in Late Miocene) Rangiferini (in Pliocene) and Cervini (pre-Illinoian) had separate histories and trajectories in the Nearctic and Neotropics (Guthrie and Matthews, 1971; Webb, 2000). Range expansion into the Neotropical region for now endemic genera and species of Rangiferini and Odocoileini occurred after 2.5 mybp (Webb, 2000). Rangifer tarandus and Cervus elaphus are first seen in Beringia by $\approx 2$ mybp (Guthrie and Matthews, 1971; Webb, 2000) and later became widespread south of continental and Cordilleran glaciers through the Late Pleistocene. Rangifer tarandus may represent a Beringian endemic and its occurrence outside this region during the Pleistocene is an indicator of harsh climate and tundra habitats (Kurtén and Anderson, 1980; Webb, 2000). In contrast, moose are late Pleistocene immigrants represented by Alces latiforns (Johnston), which entered the Nearctic from Eurasia in the Illinoian, and A. alces, which is known from the late Wisconsin of eastern Beringia, extending its range south following the retreat of con- 
tinental glaciers near the termination of the Pleistocene (Guthrie, 1968; Kurtén and Anderson, 1980).

Antilocapridae are endemic to the Nearctic, being first recognized in the Middle Miocene, where the family radiated extensively during the Pliocene and Pleistocene. Widespread extinction near the termination of the Pleistocene left the monotypic pronghorn, Antilocapra americana, as the sole representative in the Nearctic (Kurtén and Anderson, 1980). Pronghorns once ranged as far south as Florida, but the current distribution in western North America extends from southern Canada to northern Mexico.

Camelidae are basal artiodactyls that had origins in North America in the early Tertiary, and camels are first recognized in Eurasia during the Pliocene after dispersal across Beringia. Llamas also originated in North America during the Late Miocene, 7-5 mybp, and subsequently spread into South America by 3 mybp, where both Lama and Vicugna are known by the early Pleistocene (Webb, 1974). Camelids represented a diverse assemblage of 6 genera during the Pleistocene in North America but became extinct in the Nearctic prior to the Holocene (Kurtén and Anderson, 1980). Also among basal artiodactyls, the Tayassuidae are related to Palearctic pigs and have records extending from the Lower Oligocene to Recent in North America. Peccaries are known from the Late Pliocene to Pleistocene in South America (Kurtén and Anderson, 1980; Marshall et al., 1982).

Clearly the predominant direction of dispersal for the Holarctic and Beringian megafauna (and Nematodirus spp.) was from the Palearctic to the Nearctic during the Miocene, Pliocene, and Pleistocene. Significantly, there was no apparent evidence for caprines or camelids to have served a role for dispersal of a nematodirine fauna from the Nearctic to the Palearctic during the late Tertiary and Quaternary; new interpretations in the current study refute, in part, prior hypotheses articulated by Hoberg and Rickard (1988) and Hoberg et al. (1989). With respect to the Neotropical region, tayassuids, cervids (Rangiferini, Odocoileini), and camelids (llamas) arrived in South America by the Late Pliocene between 3-2 mybp, coincidental with a continuous land connection across the isthmus of Panama (Webb and Marshall, 1981; Marshall et al., 1982; Webb, 2000). Collectively, these biogeographic histories act as constraints or determinants for the distribution of $\mathrm{Nem}$ atodirus and Nematodirella.

Considering the Nearctic, there are no endemic species of Nematodirus in Bison or Tayassu tajacu, although $N$. molini occurs in $T$. pecari and $T$. tajacu from Brazil; species of the genus are also absent in Old World suids. Camelids, Lama gla$m a$, L. pacos, and Vicugna vicugna are hosts for N. lamae; species of Nematodirus characteristic of Camelus in Eurasia are unknown, although several species may be shared with domestic caprines. Among Cervidae, N. skrjabini Mitzkewitsch, 1929, occurs across the Holarctic in $R$. tarandus (and occasionally $O$. moschatus), but species of Nematodirus are unknown in Ranfigerini from the Neotropics (Pudu and Hippocamelus). Among Odocoileini, $N$. odocoilei Becklund and Walker, 1967, is a typical parasite in Odocoileus virginianus (Zimmermann) and $O$. hemionus but is occasionally reported in Oreamnos americanus and Ovis canadensis from North America, whereas N. urichi occurs in Mazama americana from the Neotropics. In the Palearctic, additional species are known in Capreolus capreolus
(Odocoileini) and Cervinae, including Cervus elaphus and $C$. dama Linnaeus, but not from any of the Muntiacini. Antilocapra shares a species, $N$. oiratianus interruptus Lichtenfels and Pilitt, 1983, with caprine hosts across its range. Apparently endemic species are characteristic of caprines in the Nearctic, including those in Ovis canadensis ( $N$. andersoni Durette-Desset and Samuel, 1989 [=N. archari Sokolova, 1948?]; N. oiratianus interruptus, $N$. davtiani Grigorian, 1949, and $N$. maculosus Becklund, 1965), Ovis dalli (N. oiratianus interruptus; $N$. davtiani) and Oreamnos americana ( $N$. becklundi Durette-Desset and Samuel, 1992; N. davtiani and N. oiratianus interruptus). Nematodirus davtiani, $N$. spathiger, $N$. archari, (?) and $N$. oiratianus are among the few Holarctic species in wild caprines; $N$. oiratianus interruptus is in the Nearctic and $N$. oiratianus oiratianus (Raevskaia, 1929) in the Palearctic, with the latter being typical in Ovis nivicola and Saiga tatarica from Siberia and Gazella subguttorosa from Iran (Lichtenfels and Pilitt, 1983a).

The greatest diversity for Nematodirus, however, is known among caprines in the Palearctic and Eurasia, where numerous species are distributed among wild and domestic Ovis spp., Capra spp., and Rupicapra rupicapra (Linnaeus), and a single species, N. gazellae Sokolova, 1948, in goitered gazelle (Kulmamatov, 1974; Rossi, 1983). It is also evident that widespread host switching among wild and domestic caprines, such as Ovis aries, and wild antelopes, including Saiga and Gazella, is common (e.g., Boev, Sokolova and Panin, 1963; Eslami et al., 1979, 1980; Bekenov et al., 1998; Morgan et al., 2004). Additionally, global translocation for N. spathiger (Railliet, 1896), N. fillicollis (Rudolphi, 1802), N. abnormalis May, 1920, N. battus, $N$. davtiani, and $N$. oiratianus in domestic sheep and $N$. helvetianus May, 1920, in cattle has been pervasive (e.g., Hoberg et al., 1985; Hoberg, 1997). Significantly, N. spathiger and N. helvetianus are also known from otherwise historically isolated populations of wild sheep and muskoxen in the Nearctic (Hoberg et al., 2001), indicating distributions that may be consistent with dual origins of these morphospecies. Phylogeographic and molecular phylogenetic studies of these parasites, similar to those in the complex of species represented by Teladorsagia circumcinta (Stadelman, 1894), may be predicted to reveal currently unrecognized diversity among Nematodirus spp. (e.g., Hoberg, et al., 1999; Leignel et al., 2002).

Initial diversification of Nematodirus among caprines in Eurasia was followed by colonization of cervids in the Palearctic (Hoberg, 1997). Subsequent radiation and range expansion for Odocoileinae and Nematodirus into North America occurred before 3 mybp. Prevailing evidence indicates that cervids, tayassuids, and camelids entered South America, where host switching by Nematodirus resulted in current diversity in the Neotropical region. Colonization and speciation by Nematodirus among cervids, such as Mazama, Lamini, and Tayassu in South America resulted in N. urichi, N. lamae, and N. molini. In the context of phylogenetic analyses, $N$. urichi and $N$. lamae are among the crown species of Nematodirus, a further indicator of the relatively recent derivation of the Neotropical fauna (Rickard and Hoberg, 1990; Hoberg, 1997). Thus, nematodirine diversity has resulted from initial radiation of caprine hosts and parasites in Eurasia, extensive host switching, and subsequent multiple invasions of North America across Beringia since the Pliocene. 
In contrast with Nematodirus, there are 6 species of Nematodirella: 3 are in the Holarctic, N. alcidis (in Alces alces), $N$. longissimespiculata (in Rangifer tarandus and Ovibos moschatus), and N. gazelli (in Gazella, Saiga, and Ovibos); 1 is endemic to the Nearctic, $N$. antilocaprae (in A. americana and occasionally in Cervus elaphus, Odocoileus hemionus, and $\mathrm{Or}$ eamnos americana); and 2 occur in the Palearctic, $N$. dromedari and $N$. cameli (in Camelus spp. and G. subguttorosa). Each species has a relatively limited distribution in respective host groups. Species of Nematodirella are unknown in the Subtropical region and none have been reported in Lamini or cervids from South America.

An unequivocal basal association for Nematodirus and caprines is also compatible with an ancestral association for $\mathrm{Ne}$ matodirella and the Antilopinae/Caprinae (rather than Camelus) in Eurasia (Fig. 1). Species of Nematodirella are found in host groups with histories of Pleistocene expansion into the Nearctic or have amphi-Beringian distributions. Compared with Nematodirus, contemporary distributions for Nematodirella are typically restricted to high latitudes. Host switching among a sympatric Pleistocene megafauna of great diversity is also apparent (Guthrie, 1982, 1984; Vareshagin and Baryshnikov, 1982). Such is compatible with the distribution of Nematodirella gazelli in Ovibos, Gazella and Saiga. Species in Camelidae are explained by a secondary switch to Camelus after their entry into Palearctic during the Pliocene. The basal species of $\mathrm{Ne}$ matodirella, however, remains unresolved and is represented by either N. gazelli or N. dromedari (Lichtenfels and Pilitt, 1983b). In contrast with that study, reanalysis confirms the unresolved position for these basal species but places $N$. alcidis as the sister of $N$. longissimespiculata $+N$. antilocaprae, suggesting a host switch from cervids to pronghorn in the Nearctic (E. P. Hoberg, unpubl. data). Probably Antilocapra acquired Nematodirella from cervids while in sympatry during glacial maxima south of the Laurentide ice during the Pleistocene (in contrast with Lichtenfels and Pilitt, 1983b). Thus, we propose a minimum of 2 independent range extensions across Beringia to the Nearctic for Nematodirella in late Pliocene and Pleistocene. The late arrival or diversification of crown species in the Nearctic is compatible with absence of Nematodirella in Lamini and from temperate/boreal latitudes of North America and from South America. Contemporary ranges for some species may also be determined by sharing of parasites among wild and domestic caprines and antelopes and cervids, respectively, in North America and Eurasia (Eslami et al., 1979, 1980; Kass and Bergstrom, 1983).

Diversification of Nematodirus and Nematodirella to some degree has paralleled that for the 7 species of Mazamastrongylus Cameron, 1935, among the Cervinae, Odocoileinae, and Lamini (Hoberg, 1996). In this regard, M. janseni (Dróżdż, 1965) and M. vietnamica (Dróżdż, 1965) occur in Muntiacus muntjak (Zimmermann) from Southeast Asia, and M. dagestanica (Altaev, 1953) is a typical ostertagiine in Capreolus capreolus, C. elaphus, and Alces alces across the Palearctic. In the Nearctic, 2 endemic species, M. odocoilei (Dikmans, 1931) and M. pursgolovei (Davidson and Prestwood, 1979), are found in Odocoileus virginianus. In the Neotropical region, $M$. trinitatus Cameron, 1935, was described in Mazama americana from Trinidad, whereas $M$. peruvianus (Guerrero and Chavév, 1967) is known in Lama pacos and L. guanicoe (Muller) and
Vicugna vicugna from Chile. These host and geographic distributions are consistent with origins in Eurasia and subsequent range expansion across Beringia into the Nearctic with the Odocoileini. Mazamstrongylus peruvianus represents colonization from cervids and subsequent speciation in Lamini after 2.5 mybp in South America (Hoberg, 1996). Similar to the putative history for Nematodirus, species of Mazamstrongylus are absent from either $C$. bactrianus or $C$. dromedarius in Eurasia.

Species of the related genus, Spiculopteragia (Orloff, 1933), did not disperse with Cervinae into the Nearctic during the Pleistocene but were subsequently introduced into temperate/ boreal latitudes of North America with C. dama and C. elaphus (Hoberg et al., 2001). Additionally, species of Ashworthius Le Roux, 1930, had origins in either Africa or Eurasia, where the group radiated in both Bovinae and Cervidae; $A$. tuyenquangi Dróżdż, 1970, occurs in $M$. muntjak from northern Vietnam, whereas A. sidemi Schulz, 1933, is typical in C. elaphus, Capreolus capreolus, and Alces alces but has been introduced and has extensively colonized caprinae and bovinae in the western Palearctic (Ferté and Durette-Desset, 1989; Dróżdż et al., 1998; Hoberg, Abrams et al., 2002). Notably, A. patriciapilittae Hoberg, Abrams, Carreno, and Lichtenfels, 2002, in O. virginianus from Costa Rica is the sole representative of this genus to be discovered in the Western Hemisphere.

Collectively, it appears that, at a minimum, the distributions for Nematodirus, Nematodirella, Mazamastrongylus, and Ashworthius exhibit replicated patterns for biogeography, indicative of a common history (see also Hoberg et al., 1999). There is some evidence to suggest that the Beringian region acted as a filter in determining which components of these respective faunas were successful in extending into the Nearctic with their hosts, coincidental with dispersal through northern regions from the Late Miocene to the Quaternary. In this respect, prior history and climatological determinants may explain the apparently divergent trajectories for species of Haemonchus among the Pecora (Hoberg et al., 2004).

\section{Faunal structure and history in the Holarctic}

Faunal mosaics constitute the underlying structure for parasite assemblages among artiodactyls in the Nearctic and may be the foundation for other regional faunas (e.g., Hoberg et al., 1999, 2001). Assemblages represent a mixture of relatively old or endemic species and components that have often been introduced recently usually in the context of translocation, introduction, and establishment of domestic or wild ruminants and their parasites in a novel geographic location (Hoberg, 1997). Essentially, a break down in mechanisms for ecological isolation is involved, but this is also true with respect to differential time frames for dispersal, as is evident for nematodirines in lagomorphs or artiodactyls between the Palearctic and Nearctic in the late Tertiary and Quaternary. This temporal aspect of dispersal and establishment (or geographic colonization) is compatible with variation in arrival and residence times for different host-parasite groups and may serve as a determinant of the relative degree of local adaptation for helminths among an array of phylogenetically disparate hosts. Thus, the mosaic is dynamic and multifaceted and has the potential to be interactive in a synergistic or negative manner (e.g., competitive exclusion) or may be neutral. The potential for host switching is then a func- 
tion of specificity of parasites, susceptibility of hosts, environmental compatibility, relative degrees of ecological similarity or isolation, host abundance, patterns of contact, and climate variation over time (Hoberg et al., 1995, 1999; Morgan et al., 2004). The relative timing of natural dispersal, or anthropogenically driven introduction, may be a significant contributing factor in the potential for and development of local adaptation for parasites in the context of hosts or environmental settings. Establishment and local adaptation may be further influenced by population sizes and densities for hosts and parasites, founder effect, generation time, and transmission dynamics for parasites and initial population density for hosts. Local adaptation may also serve as a constraint that determines the tolerance for variation within changing environments and may limit the range of potential responses to perturbations within a host-parasite system. Generalities are apparent in considering the controls and drivers for establishment following processes of passive or natural dispersal or in situations involving anthropogenic translocation (e.g., Torchin et al., 2003).

Events at the Beringian nexus since the Late Miocene have been the critical determinants of biogeographic history for the nematodirines and other Trichostrongylina among artiodactyls and lagomorphs. Although Beringia was a permanent land connection for much of the Tertiary, temporal and geographic scales for isolation since the Pliocene can be defined (Hopkins, 1959; Rausch, 1994; Sher, 1999; Hoberg et al., 2003; Galbreath and Cook, 2004). The first opening of Bering Strait was temporally deep, 4.8-5.5 mybp, and may have resulted in intercontinental isolation of east and west Beringia for a duration of nearly 1 my (Marincovich and Galdenkov, 1999; Sher, 1999). After about 3 mybp, inter- and intracontinental isolation was driven by episodic and cyclical climate change (pulselike episodic events coinciding with rapid habitat perturbation). Range expansion from Eurasia and across Beringia was linked to stadials, and Laurentide glaciation limited the continuity of faunas between a Beringian refugium and the perigalcial and open habitats south of the ice sheets in North America. Isolation of Eurasia and North America occurred during interstadials, which also promoted intercontinental expansion from the Nearctic into Neotropics after 3 mybp (Marshall et al., 1982; Webb, 2000; Hoberg et al., 2003). We have come to recognize Beringia as a center for diversification through the middle to late Cenozoic, as a region of importance for the origins of an arctic-adapted fauna, and as a primary dispersal corridor that has exerted a major influence on the history, structure, and continuity of the Holarctic biota (Hopkins, 1959; Kontrimavichus, 1976; Hopkins et al., 1982; Rausch, 1994, Sher, 1999; Galbreath and Cook, 2004).

Geographic and temporal continuity for parasite assemblages is also determined by the specific mechanism for range expansion, dispersal, successful establishment, and colonization whether on local, regional, and inter- or intracontinental scales. Hewitt (1996) discussed these issues in the context of genetic diversity, but the general concepts are also applicable at scales appropriate for interactions within host-parasite assemblages. Thus, extensive and slow range expansion involving host populations and their parasites occurring on a geographically broad front may enhance the potential for successful establishment over time. Such phalanx dispersal may minimize heterogeneity and distributional patterns consistent with peripheral isolation.
In contrast, relatively rapid, or pioneer, dispersal involving small populations or segments of larger populations may lead to patchy distributions and drive local isolation, diversification, or extinction; patterns may also be consistent with historically independent events for parasite dispersal, bottlenecks, and peripheral isolation. Under a regime of episodic climate and habitat change during the Pleistocene, the mode and tempo for host dispersal through alternating periods of range expansion and contraction will serve as a primary determinant of parasite distribution (consistent with Hewitt, 1996). Concurrently, habitat structure, host behavior and life history, and the availability of suitable refugia will further constrain or relax the controls on the overall distributions of diverse host-parasite systems. In this situation, the outcomes for natural events can serve as a model or analogue for understanding factors that either limit or facilitate the introduction of potentially invasive species under anthropogenic control.

All genera of nematodirines except Nematodirus are geographically restricted to the Northern Hemisphere. Holarctic distributions were established in relation to the Beringian nexus, leading to a prediction for partitioning of the fauna coincidental with opening of the Bering Strait and episodic isolating events through Pleistocene (Hoberg et al., 2003). Thus, the diversity for nematodirines may have been structured largely by a series of dispersal events, isolation, and serial or sequential colonization for faunas in artiodactyls or limited cospeciation (particularly evident for lagomorphs and Caprinae and Cervidae). Among artiodactyls, the Pleistocene megafauna was characterized by extensive sympatry and high diversity (e.g., species of Antilocapra, Ovis, Ovibos, Oreamnos, Saiga, Bison, Cervus, Alces, Camelus, and Lama) (Guthrie, 1982, 1984; Verashchagin and Baryshnikov, 1982), which indicates potential for colonization by parasites among ecologically similar hosts (e.g., Hoberg et al., 1995, 1999; Hoberg, Kutz et al., 2002; Morgan et al., 2004). Source communities for Nematodirus are represented by Caprini and Rupicaprini with independent colonization of cervids, Antilocapra, Bovinae, and rodents (Fig. 1.) (Hoberg et al., 1988). Additionally, the Odocoileini are the putative source for Nematodirus in tayassuids and Lamini, whereas cervids appear to be the source for Nematodirella in Antilocapra. A comprehensive species-level phylogeny for Nematodirus is necessary to reveal further details of history of association for hosts and parasites; however, the current analyses serve to establish a series of testable hypotheses along with a temporal and geographic context for understanding patterns of diversification for this complex fauna.

Sequential host switching in the diversification of Nematodirus and Nematodirella emphasizes the concept of back or retro-colonization. Essentially, this is represented by colonization events from phylogenetically young host groups to those that are basal (see Mitter and Brooks, 1983; Brooks and McLennan, 2002; Hoberg, Lichtenfels, and Gibbons, 2004). Such is indicated by incongruence in host and parasite phylogenies as has been clearly demonstrated for Nematodirus and the artiodactyls (Hoberg, 1997). For example, caprines serve as the source for parasites in Eurasian cervids and camelids, or cervids are the putative source for Nematodirus in tayassuids and Lamini in South America. Such patterns have also been revealed for relationships among species of Haemonchus and their camelid and pecoran hosts, where antelopes represent ancestral 
hosts, with extensive colonization to basal groups, including the Bovinae (Hoberg, Lichtenfels, and Gibbons, 2004).

Nematodirines are a core component of an Arctic-Boreal fauna of zooparasitic nematodes (defined by latitude and altitude) adapted to transmission in extreme environments characterized by seasonally low temperatures and varying degrees of desiccation. The primary physiographic determinant of distribution was the Beringian nexus linking the Palearctic and Nearctic permanently through much of the Tertiary and intermittently during the Pliocene and Quaternary, along with the progressive development of tundra-steppe habitats (e.g., Hopkins, 1959; Guthrie and Matthews, 1971; Sher, 1999). Beringia appears as the center of evolution for an Arctic-adapted fauna, including Nematodirella and some species of Nematodirus. This arctic or cold fauna also includes such groups as the Protostrongylidae (e.g., species of Protostrongylus Kamensky, 1905, Parelaphostrongylus Boev and Shulz, 1950, Elaphostrongylus Cameron, 1931, Umingmakstrongylus Hoberg, Polley, Gunn and Nishi, 1995), Dictyocaulidae (species of Dictyocaulus Railliet and Henry, 1907), and Ostertagiinae (e.g., species of Ostertagia Ransom, 1907, Teladorsagia Andreeva and Satubaldin, 1954, and Marshallagia (Orloff, 1933)) among cervids and caprine bovids distributed across the Holarctic (e.g., Hoberg et al., 1999; Hoberg, Kutz et al., 2002; Kutz et al., 2001).

Beringia, as it became increasingly cold, insular, and isolated with sharply defined seasons, may have acted as a filter bridge of high selectivity for parasite faunas that could not survive the expansion of rigorous climatic conditions in the late Pliocene and Pleistocene. Thus, such groups as the Haemonchinae (Haemonchus Cobb, 1898, Mecistocirrus Railliet and Henry, 1912), Cooperiinae, and Trichostrongylinae are either absent or poorly represented in the endemic Nearctic fauna. A filter bridge would also act in conjunction with the timing of association for host and parasite groups that have diversified following colonization events (Hoberg et al., 2004). Such may further explain the absence of endemic species of Haemonchus and Cooperia Ransom, 1907, where parasites may not have been associated with caprines before range expansion into the Nearctic. Distributions for species of these taxa are not strongly associated with wild ungulates, and their occurrence in North America appears linked secondarily to introductions and dissemination with domestic sheep, cattle, and goats at temperate/boreal latitudes coincidental with European contact after the 1500s (see Hoberg, 1997; Hoberg, Kocan, and Rickard, 2001; Hoberg et al., 2004). Structurally and historically, this is further consistent with the overall mosaic nature of the North American fauna (Hoberg et al., 1999, 2001).

In the context of global change and climate/habitat modification, it would be predicted that such southern faunal elements (or introduced temperate/boreal faunas) will respond to ecological disruption by northern extensions of their ranges, which may currently be limited by temperature and moisture. Such a prediction is further supported in the context of long-term evolutionary histories for Haemonchus and Cooperia in tropical and subtropical habitats of Africa. In contrast, northern faunas, such as those represented by nematodirines, ostertagiines, and some protostrongyles in ruminants, may be influenced by latitudinal or altitudinal shifts in range, increasing rates for development, reductions in generation time, broadened windows for transmission, amplification, and concomitant increases in the prevalence and intensity of infection (Hoberg, Kocan, and Rickard, 2001). Increasingly northern faunas may be associated with regulation of host populations and emergence of disease conditions among both cervids and caprines (Kutz et al., 2004).

\section{ACKNOWLEDGMENTS}

Kurt Galbreath, Ecology and Evolutionary Biology at Cornell University, and Joe Cook, Museum of Southwestern Biology, University of New Mexico, shared their ideas and enthusiasm for mammals and parasites in Beringia. Susan Kutz, Emily Jenkins, and Lydden Polley from the Department of Veterinary Microbiology, Western College of Veterinary Medicine, University of Saskatchewan, provided insightful comments on faunal diversity and structure. The manuscript represents a contribution from the Beringian Coevolution Project, a comprehensive survey and inventory of host-parasite systems and investigations of coevolution and historical biogeography of the Beringian region, supported in part by the National Science Foundation.

\section{LITERATURE CITED}

ANDREwS, J. R. H. 1973. A host-parasite checklist of helminths of wild ruminants in New Zealand. New Zealand Veterinary Journal 21: 43-47.

Audebert, F., M.-C. Durette-Desset, And N. B. Chilton. 2000. Internal transcribed space rDNA can be used to infer the phylogenetic relationships of species within the genus Nematodirus (Nematoda: Molineoidea). International Journal for Parasitology 30: 187-191.

Bekenov, A. B., Y. A Grachev, And E. J. Milner-Gulland. 1998. The ecology and management of Saiga antelope in Kazakhstan. Mammal Review 28: 1-52.

Bernard, J. 1967. Note complémentaire au sujet de Nematodirus $(=\mathrm{Ne}$ matodiroides n. gen.) zembrae. Archives de l'Institut Pastuer de Tunis 44: 443-447.

Beveridge, I., AND G. E. FORD. 1982. The trichostrongyloid parasites of sheep in South Australia and their regional distribution. Australian Veterinary Journal 59: 177-179.

Boev, S. N., I. B. Sokolova, And V. IA. Panin. 1963. Gel'minty kopytnykh zhivotnykh Kazakhstana. Tom II. Akademia Nauk Kazakhstkoi, Institut Zoologii. Izdatel'stvo Akademii Nauk Kazakhstkoi SSR, Alma-Ata, 536 p.

Brooks, D. R., AND E. P. Hoberg. 2000. Triage for the biosphere: The need and rationale for taxonomic inventories and phylogenetic studies of parasites. Comparative Parasitology 67: 1-25.

Brooks, D. R., AND D. A. MCLEnNAN. 2002. The nature of diversity: An evolutionary voyage of discovery. University of Chicago Press, Chicago, Illinois, $668 \mathrm{p}$.

Dawson, M. R. 1967. Lagomorph history and stratigraphic record. In Essays in paleontology and stratigraphy, C. Tiechert and E. L. Yochelson (eds.). University of Kansas Geology Special Publications, Volume 2, p. 287-316.

Dikmans, G. 1937. Two new species of the nematode genus Nematodirus (Trichostrongylidae) from rabbits. Proceedings of the Helminthological Society of Washington 4: 65-67.

- 1939. Two new nematodes from rodents. Proceedings of the Helminthological Society of Washington 6: 1-4.

Dróżdż, J., A. W. DemiaszKiewicz, And J. LaChowicz. 1998. Ashworthius sidemi (Nematoda: Trichostrongylidae) a new parasite of European bison, Bison bonasus (L.) and the question of independence of A. gagarini. Acta Parasitologica Polonica 43: 75-80.

DuretTe-Desset, M.-C. 1974. Murielus abei n. sp. (Nematoda: Heligmosomidae), parasite d'un lagomorphe du Népal, et remarques sur le genre Murielus Dikmans, 1939. Bulletin du Muséum National d'Histoire Naturelle 144: 419-424.

1978. Nouvelles données morphologiques sur les nématodes Trichostrongyloides des collections du United States National Museum. Bulletin du Muséum National d'Histoire Naturelle, Série 3, Zoologie 352: 135-147.

. 1979. Les Nematodirinae (Nematoda) chez ruminants et chez les lagomorphes. Annales de Parasitologie Humaine et Comparée 54: 313-339.

1983. Keys to the genera of the Superfamily Trichostrongyloi- 
dea. No. 10. CIH keys to the nematode parasites of vertebrates, $R$. C. Anderson and A. G. Chabaud (eds.). Commonwealth Agricultural Bureaux, Farnham Royal, U.K., 86 p.

- 1985. Trichostrongyloid nematodes and their vertebrate hosts: Reconstruction of the phylogeny of a parasite group. Advances in Parasitology 24: 239-306.

- I. Beveridge, And D. M. Spratt. 1994. The origins and evolutionary expansion of the Strongylida (Nematoda). International Journal of Parasitology 24: 1139-1165.

—_, and A. G. Chabaud. 1977. Essai de classification des Nématodes Trichostrongyloidea. Annales de Parasitologie Humaine et Comparée 52: 539-558.

—. AND — 1981. Nouvel essai de classification des Nématodes Trichostrongyloidea. Annales de Parasitologie Humaine et Comparée 56: 297-312.

—_, AND R. TCHEPRAKOFF. 1983. Données morphologiques sur les Trichostrongyloidea (Nematoda). I. Acanthostrongylus Travassos, 1937. II. Graphidiella Olsen 1948. Bulletin du Muséum National d'Histoire Naturelle 5: 507-514.

Eslami, A., M. Meydani, S. H. Maleki, and A. Zargarzadeh. 1979. Gastrointestinal nematodes of wild sheep (Ovis orientalis) from Iran. Journal of Wildlife Diseases 15: 263-265.

- S. RAHBARI, AND S. NiKBIN. 1980. Gastro-intestinal nematodes of gazelle, Gazella subgutturosa, in Iran. Veterinary Parasitology 7: 75-78.

Ferté, H., D. Cléva, J. Depaquit, S. Gobert, and N. Léger. 2000. Status and origin of Haemonchinae (Nematoda: Trichostrongylidae) in deer: A survey conducted in France from 1985 to 1998. Parasitology Research 86: 582-587.

thius sidemi Schuls, 1933, et A. gagarini Kostyaef 1969 (Nematoda: Trichostrongyloidea), parasites de Cervidae. Bulletin du Muséum National d'Histoire Naturelle 11: 69-77.

Galbreath, K. E., AND J. A. COOK. 2004. Genetic consequences of Pleistocene glaciations for the tundra vole (Microtus oeconomus) in Beringia. Molecular Ecology 13: 135-148.

Gatesy, J., And P. ARCTANDER. 2000. Molecular evidence for phylogenetic affinities of Ruminantia. In Antelopes, deers and relatives: Fossil record, behavioral ecology, systematics and conservation, E. S. Vrba and G. B. Schaller (eds.). Yale University Press, New Haven, Connecticut, p. 143-155.

Geist, V. 1985. On Pleistocene bighorn sheep: Some problems of adaptation, and relevance to today's American megafauna. Wildlife Society Bulletin 13: 351-359.

Govorka, Ia., L. P. Maklakova, IA. Mitukh, A. N. Pel'gunov, A. S. Rykovskit, M. K. Semenova, M. D. Sonin, B. Erkhardova-KoTRLA, AND B. IURASHEK. 1988. Gel'minty dikikh kopytnykh vostochnoi evropy. Akademiia Nauk SSSR, Laboratoriia Gel'mintologii, Moskva, $208 \mathrm{p}$.

Groves, C. P., AND P. GrubB. 1987. Relationships of living deer. In Biology and management of the Cervidae, C. M. Wemmer (ed.). Smithsonian Institution Press, Washington, D.C., p. 21-59.

GuTHRIE, D. 1968. Paleoecology of the large mammal community in interior Alaska during the Late Pleistocene. American Midland Naturalist 79: $346-363$.

- 1982. Mammals of the mammoth steppe as paleoenvironmental indicators. In Paleoecology of Beringia, D. M. Hopkins, J. V. Matthews, C. E. Schweger, and S. B. Young (eds.). Academic Press, New York, New York, p. 307-326.

- 1984. Mosaics, allelochemics, and nutrients: An ecological theory of late Pleistocene megafaunal extinctions. In Quaternary extinctions: A prehistoric revolution, P. S. Martin and R. G. Klein (eds.). University of Arizona Press, Tucson, Arizona, p. 259-298.

_. AND J. V. MATTHEwS, JR. 1971. The Cape Deceit fauna-Early Pleistocene mammalian assemblage from the Alaskan Arctic. Quaternary Research 1: 474-510.

Gvozdev, E. V., V. L. Kontrimavichus, K. M. Ryzhikov, and L. S. SHALDYBIN. 1970. Opredelitel' gel'mintov zaitseobraznykh SSSR. Izdatel'stvo Nauka, Moskva, 232 p.

HafNeR, D. J., and R. M. Sullivan. 1995. Historical and ecological biogeography of Nearctic pikas (Lagomorpha: Ochotonidae). Journal of Mammalogy 76: 302-321.

Halanych, K. M., J. R. Demboski, B. J. van Vuren, D. R. Klein, and
J. A. CoоK. 1999. Cytochrome $b$ phylogeny of North American hares and jackrabbits (Lepus, Lagomorpha) and the effects of saturation in outgroup taxa. Molecular Phylogenetics and Evolution 11: $213-221$.

Hassanin, A., AND E. J. P. Douzery. 2003. Molecular and morphological phylogenies for the Ruminantia and the alternative position of the Moschidae. Systematic Biology 52: 206-228.

HEwITT, G. M. 1996. Some genetic consequences of ice ages, and their role in divergence and speciation. Biological Journal of the Linnean Society 58: $247-276$.

HobBs, R. P. 1980. Interspecific interactions among gastrointestinal helminths of pikas of North America. American Midland Naturalist 103: $15-25$.

HoBeRG, E. P. 1996. Emended description of Mazamastrongy/us peruvianus (Nematoda: Trichostrongylidae), with comments on the relationships of Mazamastrongylus and Spiculopteragia. Journal of Parasitology 82: 470-477.

- 1997. Parasite biodiversity and emerging pathogens: A role for systematics in limiting impacts on genetic resources. In Global genetic resources: Access, ownership and intellectual property rights, K. E. Hoaglund and A. Y. Rossman (eds.). Association of Systematics Collections, Washington, D.C., p. 71-83.

- A. Abrams, R. A. Carreno, and J. R. Lichtenfels. 2002. Ashworthius patriciapilittae n. sp. (Trichostrongyloidea: Haemonchinae), an abomasal nematode in Odocoileus virginianus from Costa Rica, and a new record for species of the genus in the Western Hemisphere. Journal of Parasitology 88: 1187-1199.

- , M. Fruetel, and L. G. RicKard. 1989. Synlophe of Nematodirus odocoilei (Trichostrongyloidea) from deer and caribou in North America with comments on the evolution of Nematodirus spp. among the Cervidae (Artiodactyla). Canadian Journal of Zoology 67: 1489-1494.

- A. A. KoCAN, AND L. G. Rickard. 2001. Gastrointestinal strongyles in wild ruminants. In Parasitic diseases of wild mammals, W Samuel, M. Pybus, and A. A. Kocan (eds.). Iowa State University Press, Ames, lowa, p. 193-227.

- S. J. Kutz, K. Galbreath, And J. CoOk. 2003. Arctic biodiversity: From discovery to faunal baselines-Revealing the history of a dynamic ecosystem. Journal of Parasitology 89(supplement): S84-S95.

, J. Nagy, E. Jenkins, B. Elkin, M. Branigan, and D. COOLEY. 2002. Protostrongylus stilesi (Nematoda: Protostrongylidae): Ecological isolation and putative host-switching between Dall's sheep and muskoxen in a contact zone. Comparative Parasitology 69: 1-9.

_ of the Trichostrongylidae (Nematoda), with an initial assessment of coevolution and biogeography. Journal of Parasitology 80: 976996.

, - AND L. M. GibBons. 2004. Phylogeny for species of the genus Haemonchus (Nematoda: Trichostrongyloidea): Considerations of their evolutionary history and global biogeography among Camelidae and Pecora (Artiodactyla). Journal of Parasitology 90: $1085-1102$.

- - AND L. G. Rickard. 2005. Phylogeny for genera of Nematodirinae (Nematode: Trichostrongylina). Journal of Parasitology 91: 382-389.

- K. J. Monsen, S. Kutz, And M. S. Blouin. 1999. Structure, biodiversity, and historical biogeography of nematode faunas in Holarctic ruminants: Morphological and molecular diagnoses for Teladorsagia boreoarcticus n. sp. (Nematoda: Ostertagiinae), a dimorphic cryptic species in muskoxen, Ovibos moschatus. Journal of Parasitology 85: 910-934.

- L. POlley, A. GUnN, AND J. S. Nishi. 1995. Umingmakstrongylus pallikuukensis gen. nov. et sp. nov. (Nematoda: Protostrongylidae) from muskoxen, Ovibos moschatus, in the central Canadian Arctic, with comments on biology and biogeography. Canadian Journal of Zoology 73: 2266-2282.

$\longrightarrow$, AND L. G. RICKARD. 1988. Morphology of the synlophe of Nematodirus maculosus (Trichostrongyloidea) with comments on the evolution of Nematodirus spp. among the Caprinae (Artiodactyla). Proceedings of the Helminthological Society of Washington 55: $160-164$. 
dirus neotoma (Trichostrongyloidea). Journal of Parasitology 74: 686-691.

- G. L. Zimmerman, AND L. G. Rickard. 1985. Nematodirus battus: A review of recent studies relative to the development of surveillance and control programs. Proceedings of the United States Animal Health Association 89: 420-431.

Hopkins, D. M. 1959. Cenozoic history of the Bering land bridge. Science 129: 1519-1528.

- 1967. The Cenozoic history of Beringia-A synthesis. In The Bering land bridge, D. M. Hopkins (ed.). Stanford University Press, Stanford, Stanford, California, p. 451-484.

L, J. V. MatThews, JR., C. E. Schweger, AND S. B. Young (EDs.). 1982. Paleoecology of Beringia. Academic Press, New York, 489 p.

KASS, T. B., AND R. C. BERGSTROM. 1983. Occurrence of Nematodirella sp. (Nematoda: Trichostrongyloidea) in domestic sheep (Ovis aries) of Wyoming. Proceedings of the Helminthological Society of Washington 50: 335-336.

Kontrimavichus, V. L. (ED.). 1976. Beringia in Cenozoic. Academiia Nauk SSSR, Vladivostok, 594 p.

Korobitsnaya, K. V., C. F. Nadler, N. N. Vorontsov, and R. S. HofFMANN. 1974. Chromosomes of the Siberian snow sheep, Ovis nivicola, and implications concerning the origin of amphiberingian wild sheep (subgenus Pachyceros). Quaternary Research 4: 235245.

Kulmamatov, A. 1974. O vidovom sostave roda Nematodirus Ransom, 1907. Materialy Nauchnykh Konferentsii Vsesoiuznogo Obshchestva Gel'minotologov 26: 137-140.

Kurtén, B., AND E. ANDERSON. 1980. Pleistocene mammals of North America. Columbia University Press, New York, New York, 442 p.

Kutz, S. J., E. P. Hoberg, J. Nagy, And L. Polley. 2004. Emerging parasitic infections in Arctic ungulates. Integrative and Comparative Biology 44: 109-118

$\longrightarrow, \longrightarrow$, AND L. POLLEY. 2001. A new lungworm in muskoxen: An exploration in Arctic parasitology. Trends in Parasitology 17: 276-280.

Leignel, V., J. Cabaret, And J. F. Humbert. 2002. New molecular evidence that Teladorsagia circumcincta (Nematoda: Trichostrongylidea) is a species complex. Journal of Parasitology 88: 135140.

Lichtenfels, J. R., AND P. A. PilitT. 1983a. Cuticular ridge patterns of Nematodirus (Nematoda: Trichostrongyloidea) parasitic in domestic ruminants of North America, with a key to species. Proceedings of the Helminthological Society of Washington 50: 261-274.

- AND $-1983 \mathrm{~b}$. Cuticular ridge patterns of Nematodirella (Nematoda: Trichostrongyloidea) of North American ruminants, with a key to species. Systematic Parasitology 5: 271-285.

Maddison, D. R., AND W. P. MAdDisOn. 2000. MacClade 4.0, program and manual. Sinauer and Associates, Sunderland, Massachusetts, $492 \mathrm{p}$.

Marincovich, L., And A. Yu. Gladenkov. 1999. Evidence for an early opening of Bering Strait. Nature 397: 149-151.

Marshall, L. G., S. D. Webb, J. J. Sepkoski, and D. M. Raup. 1982. Mammalian evolution and the great American interchange. Science 215: 1351-1357.

Mitter, C., AND D. R. Brooks. 1983. Phylogenetic aspects of coevolution. In Coevolution, D. J. Futuyma and M. Slatkin (eds.). Sinauer Associates, Sunderland, Massachusetts, p. 65-98.

Morgan, E. R., E. J. Milner-Gulland, P. R. Torgerson, and G. F. MEDLEY. 2004. Ruminating on complexity: Macroparasites of wildlife and livestock. Trends in Ecology and Evolution 19: 181-188.

Nadler, S. A., E. P. Hoberg, D. S. S. Hudspeth, and L. G. Rickard. 2000. Relationships of Nematodirus species and Nematodirus battus isolates (Nematoda: Trichostrongyloidea) based on nuclear ribosomal DNA sequences. Journal of Parasitology 86: 588-601.

RauSCH, R. L. 1994. Transberingian dispersal of cestodes in mammals. International Journal for Parasitology 24: 1203-1212.

$\longrightarrow$, AND M. OHBAYASHI. 1974. On some anoplocephaline cestodes from pikas, Ochotona spp. (Lagomorpha), in Nepal, with the description of Ectopocephalium abei gen. et sp. n. Journal of Parasitology 60: 596-604.

- AND L. V. SmiRnova. 1984. The genus Schizorchis (Cestoda: Anoplocephalidae) in Eurasian pikas, Ochotona spp. (Lagomorpha:
Ochotonidae), with descriptions of a new species. Transactions of the American Microscopical Society 103: 144-156.

RickARD, L. G., AND E. P. HoBERG. 1990. Evaluation of the synlophe of Nematodirus urichi and $N$. lamae (Trichostrongyloidea) from Mazama americana and camelids (Artiodactyla) in the Neotropics. Canadian Journal of Zoology 68: 1005-1001.

Rossi, P. 1983. Sur le genre Nematodirus Ransom, 1907 (Nematoda: Trichostrongyloidea). Annales de Parasitologie Humaine et Comparée 58: 557-581.

SARWAR, M. M. 1956. Studies on some trichostrongylids of ruminants from the Indo-Pakistan sub-continent. Biologia 2: 145-215.

SEESEE, F. M. 1973. The helminth parasites of the pika, Ochotona princeps princeps (Richardson, 1828), in northern Idaho. American Midland Naturalist 89: 257-265.

Shackleton, D. S., AND S. Lovari. 1997. Classification adopted for the Caprinae survey. In Wild sheep, goats and their relatives, D. M. Shackleton (ed.). International Union for Conservation of Nature, Gland, Switzerland, p. 9-14.

SHER, A. 1999. Traffic lights at the Beringian crossroads. Nature 397: 103-104.

Skrjabin, K. I., N. P. Shikhobalova, and R. S. Shul'ts. 1954. Trichostrongylids of animals and man. Isdatel'stvo Akademii Nauk SSSR, Moskva. [English translation: 1960. The Israel Program for Scientific Translations, Jerusalem, 704 p.].

Smith, A. T., N. A. Formozov, R. S. Hoffmann, Z. Changlin, and M. A. Erbajeva. 1992. The pikas. In Rabbits, hares and pikas, status survey and conservation action plan, J. A. Chapman and J. E. C. Flux (eds.). International Union for Conservation of Nature, Gland, Switzerland, p. 14-60.

Sutton, C. A., AND M.-C. Durette-Desset. 1985. Contribucion al conocimiento de la fauna parasitological Argentina XIV. Precencia de Lamanema chavezi Becklund, 1963 (Nematoda: Molineidae, Nematodirinae) parasito de camelidos en Lagidium viscacia boxi. Bulletin du Muséum National d'Histoire Naturelle, Série 7 Séction A4: 791-794.

Travassos, L. 1937. Revisão da familia Trichostrongylidae Leiper, 1912. Mongrafias do Instituto Oswaldo Cruz 1, $512 \mathrm{p}$.

Torchin, M. E., K. D. Lafferty, A. P. Dobson, V. J. McKenzie, And A. N. KURIS. 2003. Introduced species and their missing parasites. Nature 421: 628-629.

Vereshchagin, N. K., And G. F. Baryshnikov. 1982. Paleoecology of the mammoth fauna in the Eurasian Arctic. In Paleoecology of Beringia, D. M. Hopkins, J. V. Matthews, C. E. Schweger, and S. B. Young (eds.). Academic Press, New York, New York, p. 267280.

VRBA, E. S. 1985. African Bovidae: Evolutionary events since the Miocene. South African Journal of Science 81: 263-266.

. 1995. The fossil record of African antelopes (Mammalia: Bovidae) in relation to human evolution and paleoclimate. In Paleoclimate and evolution with emphasis on human origins, E. S. Vrba, G. S. Denton, T. C. Partridge, and L. H. Burckle (eds.). Yale University Press, New Haven, Connecticut, p. 385-424.

$\longrightarrow$, AND G. B. SChaller. 2000. Phylogeny of the Bovidae based on behavior, glands, skulls, and postcrania. In Antelopes, deer and relatives: Fossil record, behavioral ecology, systematics and conservation, E. S. Vrba and G. B. Schaller (eds.). Yale University Press, New Haven, Connecticut, p. 203-222.

WEBB, S. D. 1974. Pleistocene llamas of Florida with a brief review of the Lamini. In Pleistocene mammals of Florida, S. D. Webb (ed.). University Presses of Florida, Gainesville, Florida, p. 170-259.

. 2000. Evolutionary history of the New World Cervidae. In Antelopes, deer and relatives: Fossil record, behavioral ecology, systematics and conservation, E. S. Vrba and G. B. Schaller (eds.). Yale University Press, New Haven, Connecticut, p. 38-64.

, AND L. G. Marshall. 1981. Historical biogeography of Recent South American land mammals. Pymatuning Symposia in Ecology 6: $39-52$.

WILsON, D. E., AND D. REEDER (EDS.). 1993. Mammal species of the world: A taxonomic and geographic reference (Smithsonian Series in Comparative and Evolutionary Biology). Smithsonian Institution Press, Washington, D.C., 1207 p.

YU, N., C. ZHENG, Y.-P. ZhANG, AND W.-H. Li. 2000. Molecular systematics of pikas (genus Ochotona) inferred from mitochondrial DNA sequences. Molecular Phylogenetics and Evolution 16: 85-95. 